\title{
Hepatobiliary tract and pancreatic disorders in celiac disease
}

\author{
HUGH J FREEMAN MD
}

HJ FreEman. Hepatobiliary tract and pancreatic disorders in celiac disease. Can J Gastroenterol 1997;11(1):77-81. A number of hepatobiliary tract and pancreatic disorders have been documented in patients with celiac disease. Some disorders have shared immunological or genetic factors, including chronic hepatitis, primary biliary cirrhosis and sclerosing cholangitis. Other hepatic or pancreatic pathological changes in celiac disease have been documented with severe malnutrition and malabsorption, including hepatic steatosis and pancreatic insufficiency, sometimes with pancreatic calcification. Finally, celiac disease may be associated with other very rare hepatic complications, such as hepatic $\mathrm{T}$ cell lymphoma.

Key Words: Autoimmune hepatitis, Biliary tract disease, Cirrhosis, Liver disease, Pancreatic calcification, Pancreatitis, Primary biliary cirrhosis, Sclerosing cholangitis

\section{Maladies des voies hépatobiliaires et pancréatiques}

RÉSUMÉ : Un certain nombre de maladies des voies hépatobiliaires et pancréatiques ont été documentées chez des patients atteints de maladie cœliaque. Certaines de ces maladies dépendent des mêmes facteurs immunologiques et génétiques, notamment l'hépatite chronique, la cirrhose biliaire primitive et la cholangite sclérosante. Parmi les autres anomalies hépatiques ou pancréatiques propres à la maladie cœliaque, notons la malnutrition, la malabsorption grave, y compris la stéatose hépatique et l'insuffisance pancréatique parfois accompagnée de calcification pancréatique. Finalement, la maladie cœliaque peut être associée à d'autres complications hépatiques très rares, comme le lymphome $\mathrm{T}$ du foie.
A variety of hepatobiliary tract or pancreatic disorders have been described in celiac disease. In a recent prospective study, for example, it was estimated that more than $10 \%$ of celiac disease patients had some abnormality in routine liver chemistry tests (1). In some of these patients, liver test changes were reversible after administration of a gluten-free diet, while in others, an occult, usually clinically significant liver disease was detected (1).

In some celiac patients with an associated hepatic, biliary tract or pancreatic disorder, abnormalities in laboratory chemistry tests may reflect a common immunopathogenesis (2) or may be a unique feature that directly relates to the celiac disease. Specific examples include primary biliary cirrhosis or primary (lymphocytic) sclerosing cholangitis. In others, liver chemistry test changes may be related, in part, to malnutrition resulting from malabsorption of one or more nutrients. Hepatic steatosis, sometimes massive, for example, may occur with celiac disease. Very rarely, patients may develop a specific complication of celiac disease that involves the liver, such as a T cell form of lymphoma. Hepatobiliary tract and pancreatic disorders reported in patients with celiac disease are systematically reviewed in this report.

\section{HEPATOBILIARY TRACT DISEASES}

Hepatic steatosis: The common causes of hepatic steatosis include alcohol-induced steatosis, diabetes mellitus and some forms of drug therapy, including corticosteroids. In some Third World nations, dietary protein deficiency and kwashiorkor are important causes. Intestinal malabsorption is often associated with hepatic steatosis in patients with a prior

Department of Medicine (Gastroenterology), University of British Columbia, Vancouver, British Columbia

Correspondence and reprints: Dr Hugh Freeman, ACU F-137, Gastroenterology, Vancouver Hospital (UBC Site), 2211 Wesbrook Mall, Vancouver, British Columbia V6T 1W5. Telephone 604-822-7216, fax 604-822-7236

Received for publication November 21, 1995. Accepted January 10, 1996 
jejunoileal bypass procedure for morbid obesity $(3,4)$ and in those with inflammatory bowel disease (IBD) (5). Because celiac disease is most often recognized in clinically occult or latent stages before marked nutrient depletion develops, hepatic steatosis is probably less frequent than in other intestinal diseases.

At least four patients with adult celiac disease have been described, but they all had massive fatty infiltration of the liver (6-9). Presumably lesser degrees of hepatic steatosis also occur. Most often associated with massive steatosis, elevated transaminase and alkaline phosphatase activities have been documented with altered coagulation. However, in each of these four celiac disease patients clinical and biochemical changes related to hepatic steatosis improved with a glutenfree diet. In one patient with massive hepatic steatosis (9), a gluten-free diet administered for about one year resulted in clinical, laboratory and histological improvement in the fatty changes in the liver.

The precise pathogenetic mechanisms involved in deposition of fat within the liver in patients with malabsorption associated with celiac disease require definition. After a jejunoileal bypass, for example, reduced serum levels of some essential and nonessential amino acids are well documented $(3,4)$. In addition, changes in serum amino acids have been recorded in patients with kwashiorkor $(10,11)$. On the basis of these nutritional disorders, therefore, it has been suggested that malabsorption in celiac disease leads to chronic deficiency of a lipotropic factor (choline); with an associated deficiency of pyridoxine, hepatic steatosis may result (9). Further studies in celiac disease are needed to define the incidence and mechanisms of development of hepatic steatosis.

Chronic hepatitis: In several studies transaminase values were elevated in patients with celiac disease and malabsorption $(1,12,13)$. In a Scandinavian report (12), 74 consecutive celiac disease patients had liver chemistry tests done; transaminase values were measured in 53 patients, of whom $29(55 \%)$ had elevated levels. In most patients, the transaminase values normalized with a gluten-free diet. Liver biopsies were available in 13 patients and some inflammatory change was documented in 12 . In seven of the 12 patients, chronic hepatitis and/or hepatic fibrosis was present, while in the other five less specific or reactive inflammatory changes were evident. In another Scandinavian study (13), 48 of 132 patients (36\%) had elevated transaminases; 37 of the 48 had liver biopsies, and five demonstrated chronic hepatitis. Improved liver chemistry test results after a gluten-free diet were observed in 32 patients, with complete normalization in 24. Finally, in recent study of a consecutive series of 129 patients (1) elevated transaminases were observed in 17 (13\%), and all but two patients had normalized transaminase values with a gluten-free diet. One of these patients had antinuclear antibody-positive chronic hepatitis.

Although other causes of abnormal transaminase values should be considered in patients with celiac disease (eg, alcoholic liver disease), other studies have suggested that there might be a link between chronic hepatitis and celiac disease. This is expected because both disorders have been associated with human leukocyte antigen (HLA) B8 and HLA DR 3 phenotypes $(14,15)$. In a study of 16 patients with chronic hepatitis, Lindberg et al (16) detected changes of untreated celiac disease in three patients (19\%). Further assessment of celiac disease patients with abnormal transaminase values, including use of noninvasive tests such as antinuclear antibodies and viral hepatitis screening, may be worthwhile, especially if the abnormal values persist with a gluten-free diet. Unfortunately, the role of more invasive studies, such as liver biopsy, has never been thoroughly evaluated in celiac disease. As a result, the precise frequencies of inflammatory liver disorders, including chronic hepatitis, are unknown. In a recent survey, two of 30 elderly patients (7\%) initially diagnosed after age 60 had chronic hepatitis with fibrosis or cirrhosis associated with positive antinuclear antibodies (17). It would be interesting to define the effects, if any, of a gluten-free diet and drug therapy on hepatic changes in these patients with celiac disease.

Gallstones: Several studies have focused on gallbladder function in celiac disease patients. In some patients slow emptying of the gallbladder has been documented $(18,19)$, along with impaired contraction response to fat (20). Studies of enteric endocrine cells from our laboratory demonstrated significant quantitative changes in celiac patients, including a complete absence of mucosal secretin cells in biopsies from untreated celiacs (21). In addition, studies with test meals in celiac patients have suggested that there may be an impaired secretion of cholecystokinin (22) in celiac disease or possibly impaired gallbladder responsiveness to cholecystokinin (18).

Despite these changes, there does not appear to be a significant predisposition to gallstones in celiac disease patients. In one review (23), only nine of 350 patients required cholecystectomy for gallstone disease. In a recent survey (17), six of 30 celiac disease patients initially diagnosed after age 60 had a history of gallstone disease.

Hepatic vein obstruction: Although mesenteric vascular ischemia (24) and vasculitis (25-28) have been observed in celiac disease, recent reports (29-31) of celiac children from North Africa suggested the presence of an associated BuddChiari syndrome, particularly in children from Tunisia and Algeria. Celiac disease and hepatic vein obstruction were later well documented and reported in a subsequent investigation of three adults (32). Deficiencies in antithrombin III and protein $\mathrm{C}$ were noted, and it was hypothesized that malabsorption of vitamin $\mathrm{K}$ in celiac disease might result in transient protein Cor protein $\mathrm{S}$ deficiencies. Genetic and environmental factors in this geographic area need to be explored further. For example, herb consumption and geophagy are apparently common in Algeria, and information on other dietary substances may be important.

Sclerosing cholangitis: There are several well documented cases of sclerosing cholangitis associated with celiac disease, some reported as single or multiple cases from separate centres (13,33-35). The clinical, radiological and laboratory chemistry test features of sclerosing cholangitis in patients with celiac disease did not appear to differ from the features 
recorded for primary sclerosing cholangitis occurring in the absence of celiac disease or in the presence of other associated gastrointestinal disorders such as IBD. In our report (34), however, histopathological changes of lymphocytic cholangitis were emphasized due to the predominant lymphocytic infiltrate in biliary ductal epithelium, reminiscent of the epithelial lymphocytosis in both of the 'newly described' entities: lymphocytic gastritis and lymphocytic colitis associated with celiac disease $(36,37)$.

Several recent studies have suggested that genetic and immunological factors may be important in the pathogenesis of sclerosing cholangitis (38-40). Immune complexes may be formed with a common antigenic basis, resulting in tissue damage.

To date, however, no specific antigen has been detected. Alternatively, diminished suppressor $\mathrm{T}$ cell function may permit effector cytotoxic lymphocytes to alter a modifying antigen, ie, gliadin. These effector cells may then recognize and attack a patient's histocompatibility antigens. Interestingly, the frequency of the HLA B8 and DR3 phenotype is increased in sclerosing cholangitis patients compared with control subjects $(41,42)$, and in families with both sclerosing cholangitis and IBD (43). These antigens may be present in high concentrations in both biliary and intestinal epithelial cells. Further immunological and genetic studies are required to explore this intriguing relationship between celiac disease and sclerosing cholangitis.

Primary biliary cirrhosis: Since 1978 there have been over 20 patients described with both celiac disease and primary biliary cirrhosis (44-57). Most of these patients were female. Most patients also have positive antimitochondrial antibody tests, but occasionally these may be negative (49), and some have demonstrated HLA-B8. In some, other 'autoimmune' disorders have been recorded, including dermatitis herpetiformis, renal tubular acidosis, Sjögren's syndrome and arthritis. Since both disorders tend to occur commonly in middleaged females, their concomitant detection in a single patient is not surprising. In contrast, celiac disease patients over age 60 only very rarely $(44,47,49)$ develop primary biliary cirrhosis; this may reflect, in part, a reduced life expectancy due to the cirrhosis.

Patients with both diseases may share many common clinical features. Weight loss, malabsorption, bone disease, steatorrhea and elevated alkaline phosphatase activities are frequent in both celiac disease and primary biliary cirrhosis. Thus, at an early stage of their coexistence, celiac disease or primary biliary cirrhosis may not be readily recognized. In all patients reported with both disorders, regardless of geographical origin or race, restriction of dietary gluten caused cessation of diarrhea, weight gain or both, but abnormal liver chemistry tests were not improved despite a gluten-free diet.

Hepatic malignancies: Although hepatocellular carcinoma has been described in one patient, cirrhosis was also present (58). Occasionally the liver may be involved with lymphoma, the most frequently detected malignant disorder in celiac disease patients (59). In some patients, lymphomatous deposits have been detected in the liver, presumably as metastatic lesions (58). In one report, for example, lymphoma was apparently secondary to jejunal lymphoma, complicating celiac disease (58). In general, hepatic involvement in celiac patients with lymphoma is limited and overshadowed by the clinical course of the intestinal disease. In a recent report (60), a fulminant cholestatic syndrome developed in a celiac disease patient, resulting in hepatic failure. Later investigations revealed widespread hepatic involvement with an unusual lymphoid neoplasm classified as a hepatosplenic lymphoma, a rare type of peripheral $\mathrm{T}$ cell lymphoma with rearrangement of the gamma-delta $\mathrm{T}$ cell receptor $(61,62)$.

\section{CHRONIC PANCREATIC DISEASES}

Although celiac disease has been associated with diabetes, the coexistence of advanced pancreatic exocrine insufficiency and celiac disease has been recorded only occasionally (63-70). Pancreatic calcification is most often associated with chronic or persisting pancreatic inflammation which, in North America, is usually due to excessive consumption of alcoholic beverages. Atrophy, fibrosis and altered pancreatic function have been observed in experimental animals treated with diets deficient in protein (71), in adults with protein-energy malnutrition (72), in children with kwashiorkor $(73,74)$ and in some early autopsy studies of patients with celiac disease (75). In addition, pancreatic calcification has been reported with chronic protein malnutrition in the Indian subcontinent and in some African countries (71). Finally, a patient with celiac disease and tropical calcific pancreatitis has recently been described (76).

Although the precise frequency of pancreatic disease in patients with celiac disease is unknown, impaired pancreatic function must occur more often than is appreciated. For example, it was estimated that over $20 \%$ of children with celiac disease may have defective exocrine pancreatic function (77), which may be due to a number of factors. Impaired elaboration and/or release of pancreatic stimulating hormones from the diseased proximal small intestine may result (22). This has been associated with immunocytochemical evidence of alterations in enteric endocrine cells; in particular, secretin cells were noted to be absent from biopsies of untreated celiac disease patients (21). Studies with test meals in celiac patients have also suggested impaired secretion of cholecystokinin-pancreozymin, which results in impaired pancreatic exocrine cell stimulation (78). In addition, a deficiency of amino acids may result in part from impaired uptake of amino acids in the small intestine, leading to a reduction in precursor materials for pancreatic enzyme synthesis $(11,66)$. Finally, protein malnutrition may lead to pancreatic structural changes, including acinar cell atrophy and pancreatic fibrosis $(11,75)$, leading to impaired pancreatic exocrine function.

\section{FUTURE CONSIDERATIONS}

Recognition of hepatobiliary tract and pancreatic diseases in patients with celiac disease is increasing. Unsuspected or clinically occult celiac disease is also being detected in this 
setting. In the future, screening of large population groups with idiopathic or cryptogenic chronic liver diseases, for example, may be particularly productive in further delineation of this intriguing co-relationship and improve detection of occult or latent celiac disease. In a recent Swedish study (79), a microenzyme-lined immunosorbent assay for gliadin antibodies was used to examine the sera of 327 consecutive patients with chronic liver disease. In 19 patients (6\%) positive tests were detected and, in most, a small intestinal biopsy confirmed the presence of previously undiagnosed celiac disease. Interestingly, the liver disorder was previously considered 'cryptogenic' in most of the patients before detection of celiac disease. It remains to be determined whether earlier detection and gluten-free diet treatment has a beneficial effect on hepatic function.

\section{REFERENCES}

1. Dickey W, McMillan SA, Collins SA, Watson RGP, McLoughlin JC, Love AHG. Liver abnormalities associated with celiac sprue. How common are they, what is their significance, and what do we do about them? J Clin Gastroenterol 1995;20:290-2.

2. Strober W, James SP. The immunopathogenesis of gastrointestinal and hepatobiliary diseases. JAMA 1987;258:2962-9.

3. Holzbach RT. Hepatic effects of jejunoileal bypass for morbid obesity. Am J Clin Nutr 1977;30:43-52.

4. Moxley RT, Pozefsky T, Lockwood DH. Protein nutrition and liver disease after jejunoileal bypass for morbid obesity. N Engl J Med 1974;290:921-6.

5. Kern F. Hepatobiliary disorders in inflammatory bowel disease. Prog Liver Dis 1976;5:575-89.

6. van Togeren IHM, Breed WPM, Corstens FHM. Fatty liver and malabsorption. Folia Med Nederl 1972;15:246-58.

7. Puchelle JC, Lederlin P, Rauber G. Adult celiac disease: presentation with fatty liver and autoimmune hemolytic anemia. Ann Med Nancy 1976;15:41-4.

8. Capron JP, Sevenet F, Quenym C. Massive fatty liver revealing adult celiac disease: report of a case and review of the literature. Gastroenterol Clin Biol 1983;7:256-60.

9. Naschitz JE, Yeshurun D, Zuckerman E, Arad E, Boss JH. Massive hepatic necrosis complicating adult celiac disease: report of a case and review of the literature. Am J Gastroenterol 1987;82:1186-9.

10. Padilla H, Sanchez A, Powell RN. Plasma amino acids in children from Guadalajara with kwashiorkor. Am J Clin Nutr 1962;11:517-24.

11. Freeman HJ, Kim YS, Sleisenger MH. Protein digestion and absorption. Normal mechanisms and protein-energy malnutrition. Am J Med 1979;67:1030-6.

12. Hagander B, Brandt L, Sjolund K, Berg NO, Norden A, Stenstam M. Hepatic injury in adult coeliac disease. Lancet 1970;ii:270-2.

13. Jacobsen MB, Fausa O, Elgjo K, Schrumpf E. Hepatic lesions in celiac disease. Scand J Gastroenterol 1990;25:656-62.

14. Krawitt EL. Autoimmune hepatitis: classification, heterogenicity and treatment. Am J Med 1994:96(Suppl 1A):23S-6S.

15. Marsh MN. Gluten, major histocompatibility complex and the small intestine: A molecular and immunologic approach to the spectrum of gluten sensitivity ("celiac sprue"). Gastroenterology 1992;102:330-54.

16. Lindberg J, Ahren C, Iwarson S. Intestinal villous atrophy in chronic active hepatitis. Scand J Gastroenterol 1979;14:1015-8.

17. Freeman HJ. Clinical spectrum of biopsy-defined celiac disease in the elderly. Can J Gastroenterol 1995;9:42-6.

18. Braganza J, Howat HT. Gall bladder inertia in coeliac disease. Lancet $1971 ; \mathrm{i}: 1133$

19. Low-Beer TS, Heaton KW, Heaton ST, Read AE. Gall bladder inertia and sluggish enterohepatic circulation of bile salts in coeliac disease. Lancet 1971;i:991-4.

20. Low-Beer TS, Harvey RF, Davies ER, Read AE. Abnormalities in serum cholecystokinin and gall bladder emptying in coeliac disease. N Engl J Med 1975;292:961-3.

21. Buchan AMJ, Grant S, Brown J, Freeman HJ. A quantitative study of a range of regulatory peptide containing cells in celiac sprue. J Pediatr Gastroenterol Nutr 1984;3:665-71.
22. DiMagno EP, Go VLW, Summerskill WHJ. Impaired cholecystokininpancreozymin secretion, intraluminal dilution, and maldigestion of fat in sprue. Gastroenterology 1972;63:25-32.

23. Cooke WT, Holmes GKT. Coeliac Disease. New York: Churchill-Livingstone, 1984:88.

24. Upadhyay R, Park RHR, Russel RI, Danesh JJZ, Lee FD. Acute mesenteric ischaemia: A presenting feature for coeliac disease? BMJ 1987;295:958-9.

25. Doe WF, Evans D, Hobbs JR, Booth CC. Coeliac disease, vasculitis, and cryoglobulinemia. Gut 1972;13:112-23.

26. Meyers S, Dikman S, Spiera H, Schultz N, Janowitz HD. Cutaneous vasculitis complicating coeliac disease. Gut 1981;22:61-4.

27. Alegre VA, Winkelmann RK, Diez-Martin JL, Banks PM. Adult celiac disease, small and medium vessel cutaneous necrotizing vasculitis, and T cell lymphoma. J Am Acad Dermatol 1988;19:973-8.

28. Simila S, Kokkonen J, Kallionen M. Cutaneous vasculitis as a manifestation of coeliac disease. Acta Pediatr Scand 1982;71:1051-4.

29. Gentil-Kocher S, Bernard O, Brunelle F. Budd-Chiari syndrome in children: report of 22 cases. J Pediatr 1988;113:30-8.

30. Boudina T, Ghram N, Ben Becher S. Syndrome de Budd-Chiari et atrophie villositaire totale chez l'enfant: a propos de trois observations. Tunis Med 1990;68:59-62.

31. Hamdi A, Ayachi R, Saad H, Gargouri R, Zouari K, Chebbah MS. Hemiplegie revelant un syndrome de Budd-Chiari associe a une maladie coeliaque chez un nourrisson. Presse Med 1990;19:1011-2

32. Marteau P, Cadranel J-F, Messing B, Gargot D, Valla D, Rambaud $\mathrm{J}$-C. Association of hepatic vein obstruction and coeliac disease in North African subjects. J Hepatol 1994;20:650-3.

33. Hay JE, Wiesner RH, Shorter RG, LaRusso NF, Baldus WP. Primary sclerosing cholangitis and celiac disease. A novel association. Ann Intern Med 1988;109:713-7.

34. Freeman HJ, Kwan WCP. Occult celiac disease associated with lymphocytic sclerosing cholangitis. Can J Gastroenterol 1994;8:249-52.

35. Tysk C. Concurrent ulcerative colitis, celiac sprue, and primary sclerosing cholangitis. J Clin Gastroenterol 1994;18:241-2.

36. Wolber R, Owen D, DelBuono L, Appelman H, Freeman HJ. Lymphocytic gastritis in patients with celiac sprue or sprue-like intestinal disease. Gastroenterology 1990;98:310-5.

37. Wolber R, Owen D, Freeman HJ. Colonic lymphocytosis in patients with celiac sprue. Hum Pathol 1990;21:1092-6.

38. McFarlane IG, Wojcicka BM, Tsantoulas DC, Portmann BC, Eddleston AL, Williams R. Leukocyte migration inhibition in response to biliary antigens in primary biliary cirrhosis, sclerosing cholangitis, and other chronic liver diseases. Gastroenterology 1979;76:1333-40.

39. Bodenheimer HC, LaRusso NF, Thayer WR, Charland C, Staples PJ, Ludwig J. Elevated circulating immune complexes in primary sclerosing cholangitis. Hepatology 1983;3:150-4.

40. Minuk GY, Angus M, Brickman CM. Abnormal clearance of immune complexes from the circulation of patients with primary sclerosing cholangitis. Gastroenterology 1985;88:166-70.

41. Chapman RW, Varghese Z, Gaul R, Patel G, Kikinon N, Sherlock S. Association of primary sclerosing cholangitis with HLA-B8. Gut 1983;24:38-41.

42. Schrumpf E, Fausa O, Forre O. HLA antigens and immunoregulatory $\mathrm{T}$ cells in ulcerative colitis associated with hepatobiliary disease. Scand J Gastroenterol 1982;17:187-91.

43. Quigley EMM, LaRusso NF, Ludwig J, MacSween RNM, Birnie GG, Watkinson G. Familial occurrence of primary sclerosing cholangitis and ulcerative colitis. Gastroenterology 1983;85:1160-5.

44. Logan RFA, Ferguson A, Finlayson NDC, Weir DG. Primary biliary cirrhosis and celiac disease - an association? Lancet 1978;i:230-3.

45. Craxi A, Pinzello G, Oliva A, Pagliaro L. Primary biliary cirrhosis and coeliac disease. Lancet 1978;i:713.

46. Lee FI, Murray SM, Norfolk D, Vasudev KS. Primary biliary cirrhosis and coeliac disease. Lancet 1978;i:716.

47. Iliffe GD, Owen DA. An association between primary biliary cirrhosis and jejunal villous atrophy resembling celiac disease. Dig Dis Sci 1979;24:802-6.

48. Olsson R, Kagevi I, Rydberg L. On the occurrence of primary biliary cirrhosis and intestinal villous atrophy. Scand J Gastroenterol 1982;17:625-8.

49. Shanahan F, O'Regan PF, Crowe JP. Primary biliary cirrhosis associated with coeliac disease. Ir Med J 1983;76:282. 
50. Schrijver G, van Berge Henegouwen GP, Bronkhorst FB. Gluten-sensitive coeliac disease and primary biliary cirrhosis syndrome. Neth J Med 1984;27:218-21.

51. Gabrielsen TO, Hoel PS. Primary biliary cirrhosis associated with coeliac disease and dermatitis herpetiformis. Dermatologica 1985;170:31-4.

52. Lofgren J, Jarnerot G, Danielsson D, Hemdal I. Incidence and prevalence of primary biliary cirrhosis in a defined population in Sweden. Scand J Gastroenterol 1985;20:647-50.

53. Fouin-Fortunent H, Duprey F, Touchais O, Hemet J, Galmiche JP, Colin R. Celiac disease associated with primary biliary cirrhosis. Gastroenterol Clin Biol 1985;9:641-2.

54. Behr W, Barnert J. Adult celiac disease and primary biliary cirrhosis. Am J Gastroenterol 1986;81:796-9.

55. Whitehead EM, Daly JG, Hayes JR. Renal tubular acidosis in association with Sjogren's syndrome, primary biliary cirrhosis and coeliac disease. Ir J Med Sci 1987;156:124-5.

56. Ginn P, Workman RD. Primary biliary cirrhosis and adult celiac disease. West J Med 1992;156:547-9.

57. Freeman HJ. Celiac disease associated with primary biliary cirrhosis in a Coast Salish native. Can J Gastroenterol 1994;8:105-7.

58. Pollock DJ. The liver in coeliac disease. Histopathology 1977;1:421-30

59. Freeman HJ. Neoplastic disorders in 100 patients with celiac disease. Can J Gastroenterol 1996;10:163-6.

60. Freeman HJ. Fulminant liver failure with necrotizing foci in the liver, spleen and lymph nodes in celiac disease due to malignant lymphoma. Can J Gastroenterol 1996;10:225-9.

61. Harris NL, Jaffe ES, Stein H, et al. A revised European-American classification of lymphoid neoplasms: a proposal from the International Lymphoma Study Group. Blood 1994;84:1361-92.

62. Farcet J, Gaulard P, Marolleau J, et al. Hepatosplenic T-cell lymphoma: sinusal/sinusoidal localization of malignant cells expressing the T-cell receptor gamma-delta. Blood 1990;75:2213.

63. Benson GD, Kowlessar OD, Sleisenger MH. Adult celiac disease with emphasis upon response to the gluten-free diet. Medicine (Baltimore) 1964:43:1-40.

64. Pink IJ, Creamer B. Response to a gluten-free diet of patients with the coeliac syndrome. Lancet 1967;i:300-4.

65. Bustos Fernanez L, De Paula A, Prizont R, et al. Exocrine pancreas insufficiency secondary to glutenenteropathy. Am J Gastroenterol 1970;53:564-9.

66. Weinstein LD, Herskovic T. Rectal seepage of oil in a patient with celiac disease and secondary pancratic insufficiency. Am J Dig Dis 1968;13:762-5.

67. Regan PT, DiMagno EP. Exocrine pancreatic insufficiency in celiac sprue. A cause of treatment failure. Gastroenterology 1980;78:484-7.

68. Fitzgerald O, Fitzgerald P, Fennelly J, McMullin JP, Boland SJ. A clinical study of chronic pancreatitis. Gut 1963;4:193-216.

69. Pitchumoni CS, Thomas E, Balthazar E, Sherling B. Chronic calcific pancreatitis in association with celiac disease. Am J Gastroenterol 1977;68:358-61.

70. Freeman HJ, Whittaker JS. Nonalcoholic chronic pancreatitis with pancreatic calcification: presenting manifestation of occult celiac disease. Can J Gastroenterol 1994;8:319-22.

71. Pitchumoni CS. Pancreas in primary malnutrition disorders. Am J Clin Nutr 1973;26:374-9.

72. Tandon BN, George PK, Sama SK, Ramachandran K, Gandhi PC. Exocrine pancreatic function in protein-calorie malnutrition disease of adults. Am J Clin Nutr 1969;22:1476-82.

73. Davis JNP. Essential pathology of kwashiorkor. Lancet 1948;i:317-20.

74. Thompson MD, Trowell HG. Pancreatic enzyme activity in duodenal contents of children with a type of kwashiorkor. Lancet 1952;i:1031-3.

75. Adlersberg D, Schein J. Clinical and pathologic studies in sprue. JAMA 1947;134:1459-67.

76. Nanda R, Anand BS. Celiac disease and tropical calcific pancreatitis. Am J Gastroenterol 1976;66:117-39.

77. Carroccio A, Iacono G, Montalto G, et al. Exocrine pancreatic function in children with coeliac disease before and after a gluten-free diet. Gut 1991;32:796-9.

78. DiMagno EP, Go VLW, Summerskill WHJ. Relations between pancreatic enzyme outputs and malabsorption in severe pancreatic insufficiency. N Engl J Med 1973;288:813-5.
79. Lindgren S, Sjoberg K, Eriksson S. Unsuspected celiac disease in chronic 'cryptogenic' liver disease. Scand J Gastroenterol 1994;29:661-4. 


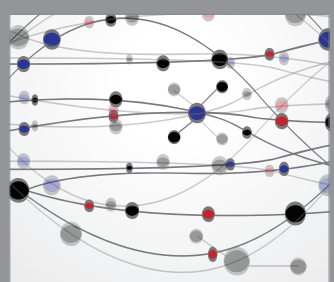

The Scientific World Journal
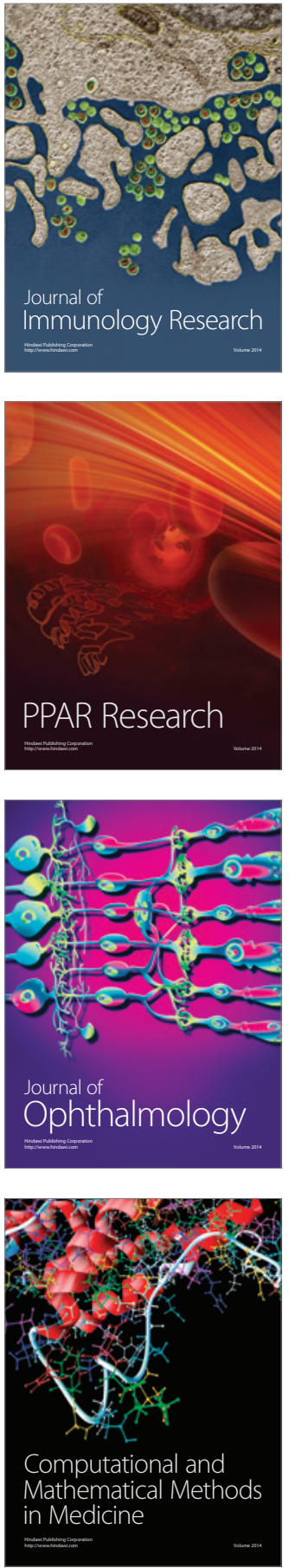

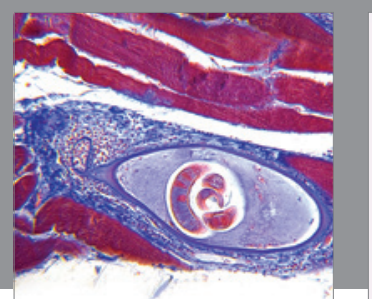

Gastroenterology Research and Practice

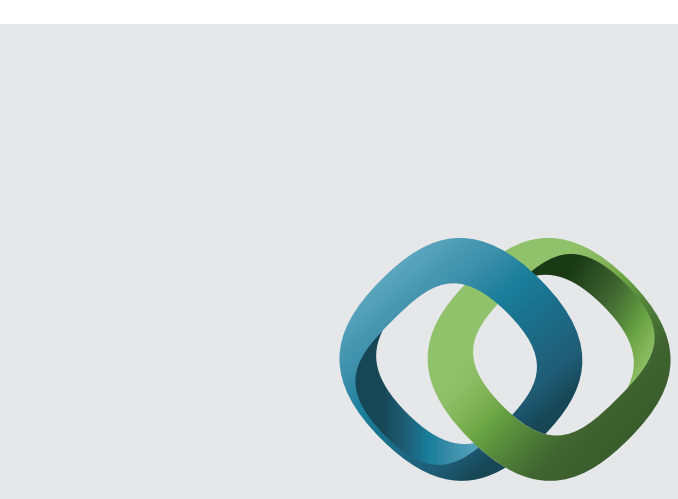

\section{Hindawi}

Submit your manuscripts at

http://www.hindawi.com
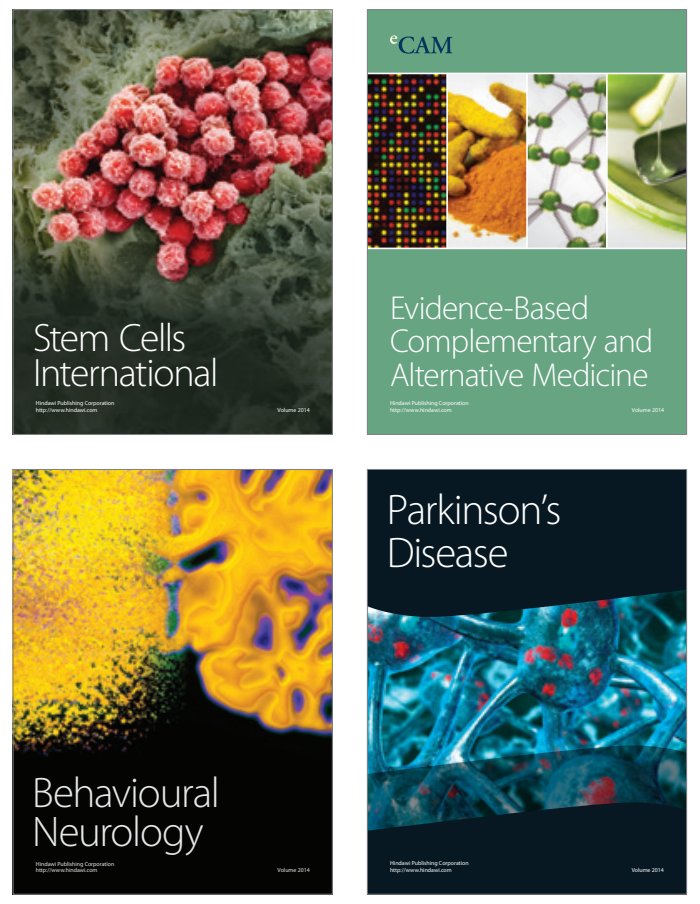
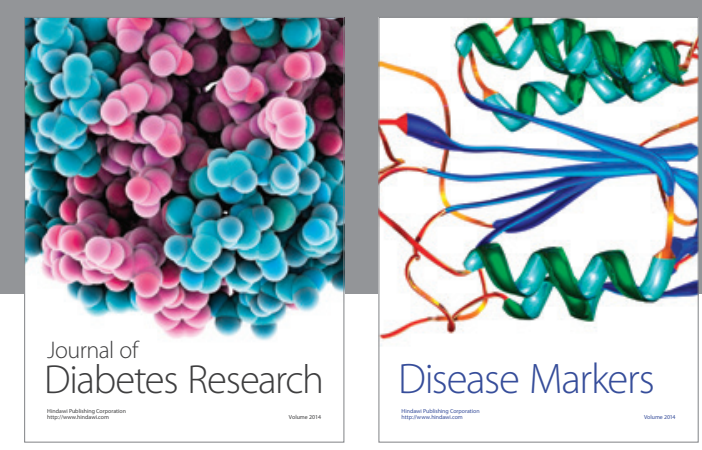

Disease Markers
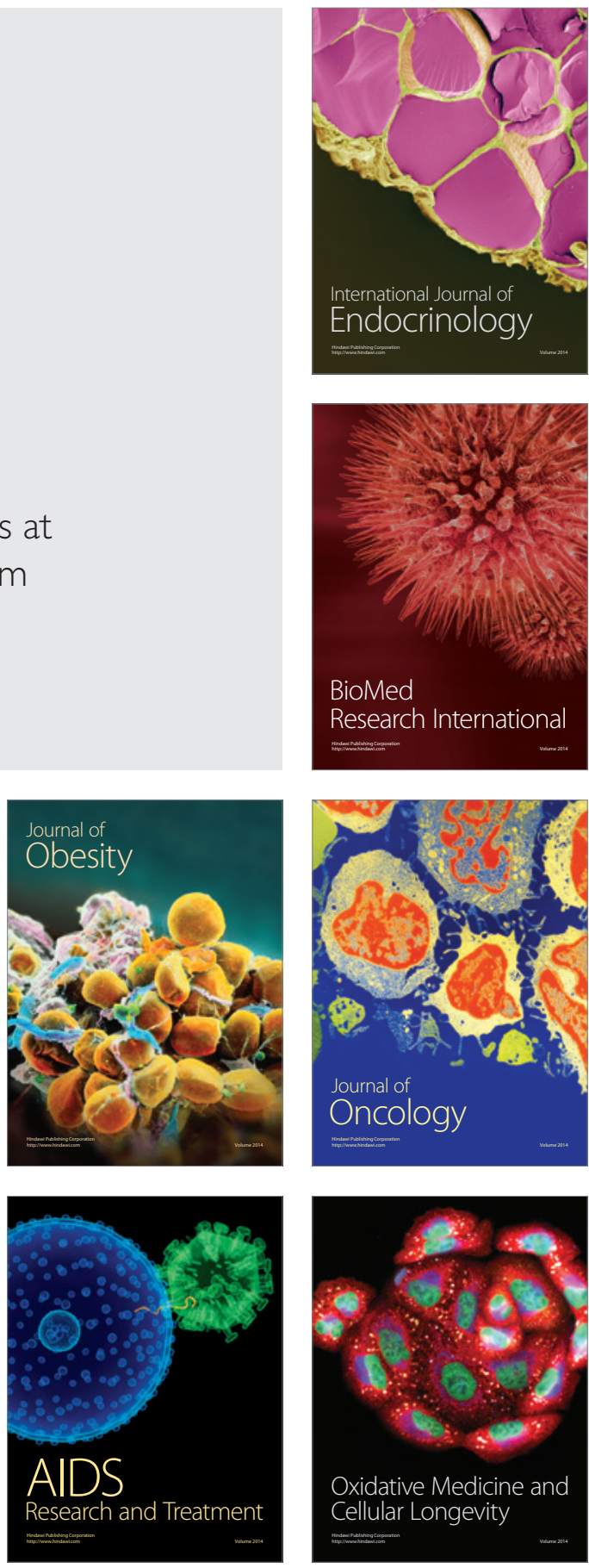